\title{
COMPLAINT TO THE COURT IN THE LIGHT OF THE ACT OF 29 JANUARY 2004 ON PUblic Procurement LaW
}

\author{
SKARGA DO SĄDU W ŚWIETLE USTAWY \\ Z DNIA 29 STYCZNIA 2004 R. PRAWO ZAMÓWIEŃ \\ PUBLICZNYCH
}

\begin{abstract}
The main research goal of this article is to show how participants in public procurement proceedings can fight for their rights before a court.

The article presents the necessary formal conditions for lodging a complaint and the rules for its recognition. The article uses primarily the dogmatic and legal method.

The article presents practical difficulties related to the provisions included in the Public Procurement Law in the scope of complaints to the court.

The conclusion of the article is that although the Public Procurement Law has been in force for fifteen years and has undergone many changes witch were supposed to improve it, it is still unclear and difficult for the participants of the proceedings to apply.

The above causes that participants of public procurement proceedings often have to take advantage of legal protection measures, which are to be used to ensure compliance of public procurement procedures and competitions with the provisions of the Act.

The question is, are the rules clear enough and do not limit the right to the court?
\end{abstract}




\section{STRESZCZENIE}

Głównym celem badawczym przedmiotowego artykułu jest wykazanie tego, na jakich zasadach podmioty postępowania zamówień publicznych mogą walczyć o swoje prawa przed sądem oraz z jakimi trudnościami wiąże się wystąpienie ze skargą do sądu.

Artykuł opisuje niezbędne warunki formalne dla wniesienia skargi oraz zasady jej rozpoznawania. W tekście posłużono się głównie metodą dogmatyczno-prawną.

Artykuł prezentuje zarówno teoretyczne zagadnienia naukowe, jak i praktyczne trudności związane z zapisami ujętymi w ustawie Prawo zamówień publicznych, w zakresie skargi do sądu.

Wnioskiem artykułu jest przede wszystkim to, że pomimo że ustawa Prawo zamówień publicznych funkcjonuje piętnaście lat i w tym czasie ulegała wielu zmianom, które miały służyć jej ulepszeniu, nadal jest niejasna oraz trudna w stosowaniu dla uczestników postępowania. To powoduje, że uczestnicy postępowania zamówień publicznych niejednokrotnie muszą skorzystać ze środków ochrony prawnej, które to mają służyć zapewnieniu zgodności postępowań o udzielenie zamówień publicznych i konkursów z przepisami ustawy.

Tylko czy przepisy są wystarczająco jasne i nie ograniczają prawa do sądu podmiotom postępowania zamówień publicznych?

KEYWORDS: complaint, deadline for bringing a complaint to court, costs of lodging a complaint, complaint recognition mode, court recognition of the complaint, cassation complaint by the president of the public procurement office

SŁOWA KLUCzOWE: skarga, termin na wniesienie skargi, koszty wniesienia skargi, tryb rozpoznawania skargi, skarga kasacyjna prezesa urzędu zamówień publicznych

\section{WPROWADZENIE}

Postępowanie skargowe jest szczególnym postępowaniem prowadzonym przed sądem, które regulują przepisy Kodeksu postępowania cywilnego o apelacji, jeżeli przepisy Prawa zamówień publicznych nie stanowią inaczej. W przepisach ustawy Prawo zamówień publicznych postępowanie dotyczące wniesienia skargi zostało zawarte w art. 198a-198g. Wyżej wymienione przepisy ustawy Prawa zamówień publicznych są przepisami szczególnymi, lex specialis w stosunku do przepisów Kodeksu postępowania cywilnego o apelacji i w związku z tym mają przed nimi pierwszeństwo. Znaczy to tyle, że sąd 
powszechny stosuje wskazane wyżej przepisy Prawa zamówień publicznych, a w sprawach, które nie są uregulowane tymi przepisami, stosuje przepisy kpc o apelacji. Głównym przyjętym w niniejszym artykule problemem badawczym jest wykazanie, za pomocą metody dogmatyczno-prawnej tego, z jakimi trudnościami mogą borykać się podmioty postępowania zamówień publicznych, które na podstawie obowiązujących przepisów prawa wystąpią ze skargą do sądu w świetle ustawy Prawo zamówień publicznych (dalej Pzp).

\section{SKARGA DO SĄDU - ODPOWIEDNIE STOSOWANIE PRZEPISÓW KPc O APELACJI}

Na gruncie ustawy Kodeksu postępowania cywilnego apelacja obok zażalenia jest jednym $\mathrm{z}$ dwóch środków odwoławczych. Wniesienie jednego ze środków odwoławczych prowadzi do rozpoznania sprawy przez sąd wyższej instancji. Ponadto wniesienie apelacji od orzeczenia nieprawomocnego powoduje wstrzymanie jego uprawomocnienie się. Apelacja służy merytorycznemu rozpoznaniu sprawy przy udziale sądu drugiej instancji w zakresie określonym przez skarżącego. Apelacja przysługuje od wyroków sądów pierwszej instancji oraz od wyroków częściowych, wstępnych oraz wyroków zapadających na skutek wniosku o uzupełnienie wyroku, a także wyroków zapadających po zarządzeniu przez sąd o połączeniu oddzielnych spraw, celem ich rozstrzygnięcia lub łącznego rozpoznania. W postępowaniu nieprocesowym apelacja jest środkiem przysługujących w sprawach dotyczących postanowień sądu pierwszej instancji orzekających co do istoty sprawy (Biedroń, komentarz do art. 367, kpc w: Marszałkowska-Krześ, 2018).

Właściwy skład sądu podczas rozpoznawania apelacji to skład trzech sędziów zawodowych. Powinno się jednak uwzględnić, że w postępowaniu apelacyjnym w związku z art. $391 \S 1 \mathrm{kpc}$ stosuje się również art. $323 \mathrm{kpc}$, na podstawie którego wyrok może być wydany wyłącznie przy udziale sędziów, którzy uczestniczyli w rozprawie poprzedzającej wydanie wyroku. Skład sądu, który jest sprzeczny z przepisami prawa, wiąże się z nieważnością postępowania (komentarz do art. 367 kpc, w: Góra-Błaszczykowska, t. I. Komentarz. Art. 1-729, 2016; Dolecki, Wiśniewski, 2011).

Przepis art. 198a ust. 2 ustawy Pzp w swojej treści odnosi się do odpowiedniego stosowania przepisów o apelacji i przemawia za uznaniem jej za śro- 
dek odwoławczy, który przysługuje do orzeczeń o charakterze zarówno merytorycznym, jak i formalnym, który łączy cechy apelacji, a także zażalenia.

Zaznaczenia wymaga, że skarga do sądu przysługuje na orzeczenie Krajowej Izby Odwoławczej, zarówno na wyrok wydawany po merytorycznym rozstrzygnięciu sprawy, jak i wyrok rozstrzygający o uwzględnieniu lub oddaleniu odwołania, a także na postanowienie kończące w sprawie oraz postanowienie w sprawie zasądzenia kosztów postępowania. Spośród postanowień kończących postępowanie w sprawie, od których przysługuje skarga, można wymienić: postanowienie o zwrocie odwołania, wydane przez Izbę, postanowienie o odrzuceniu odwołania, postanowienie o umorzeniu postępowania odwoławczego (Jaworska, 2018).

Sąd Okręgowy w Warszawie w dniu 3 kwietnia 2003 r. (postanowienie Sądu Okręgowego w Warszawie z dnia 3 kwietnia 2003 r. sygn. akt: V Ca 1514/03) wskazał istotę postępowania skargowego, uznając, że z przepisów o apelacji, które są zawarte w rozdziale I działu V kpc względem postępowania skargowego, należy stosować głównie uregulowania proceduralne, ponieważ o dopuszczalności skargi oraz jej podstawach mogą decydować przepisy o zamówieniach publicznych. Zdaniem sądu, jeśli ustawodawca nie odwoła się do innych przepisów kpc, np. dotyczących wznowienia postępowania, uznać należy, że skarga zmierzająca do wznowienia postępowania nie jest dopuszczalna.

Ponadto Sąd Okręgowy w Krakowie w postępowaniu z dnia 7 kwietnia 2005 r. (postanowienie Sądu Okręgowego w Krakowie z dnia 7 kwietnia 2005 r., sygn. akt: II Ca 474/05) stwierdził, że skarga, która składana jest w trybie przepisów ustawy Pzp, rozpoczyna proces, choć trudno porównać ją do pozwu jako pisma rozpoczynającego proces sądowy. Przepisy Pzp nadają skardze kształt apelacji, jaką sąd rozpoznaje w ramach przepisów kpc. Jeśli jednak do postępowania skargowego odnosić przepisy o postępowaniu apelacyjnym, należy wskazać, że zarówno skarżący, jak i druga strona postępowania odwoławczego występują $\mathrm{w}$ określonych rolach procesowych po stronie powoda oraz pozwanego. Korzystanie na podstawie Pzp z przepisów o procesie w zrozumiały sposób dopuszcza udział w procesie osoby, które wykażą, że mają interes prawny w rozstrzygnięciu o danej treści, które to osoby mają prawo przystąpić do postępowania w charakterze interwenienta 
ubocznego, po stronie, z którą mają wspólny interes w sprawie. Interwencja uboczna jest zatem zawsze przystąpieniem przy stronie, która już uczestniczy w procesie, a nie jest instytucją, która to może ukształtować proces oraz obsadzić strony w konkretnych zgodnych z własną intencją rolach procesowych. Zmiana tej kolejności doprowadziłaby do sytuacji, w której poddawałoby się weryfikacji najistotniejsze przesłanki dopuszczalności interwencji, a to nic innego jak interes prawny w rozstrzygnięciu sprawy.

\section{Podmioty UPRAWNIONE DO WNIESIENIA SKARGI}

Określonym ustawowo w art. 179 ustawy Pzp kategoriom podmiotów przysługują środki ochrony prawnej. Spośród nich wyróżniamy: wykonawców, uczestników konkursu oraz inne podmioty. Zgodnie z powoływanym wyżej przepisem legitymację do wniesienia skargi do sądu posiada wykonawca, uczestnik konkursu, a także inny podmiot, jeżeli ma albo miał interes w uzyskaniu określonego zamówienia, a także poniósł bądź mógł ponieść szkodę w wyniku naruszenia przez zamawiającego przepisów ustawy (Jaworska, 2018).

Definicja wykonawcy jest pojęciem prawnym, choć określane dotąd legalne definicje mają głównie charakter sprawozdawczy. W prawie unijnym definicja wykonawcy została sprowadzona do roli wyłącznie technicznej. Zgodnie z art. 1 ust. 1 pkt 10 Dyrektywy Parlamentu Europejskiego i Rady 2014/24/UE z dnia 26 lutego 2014 r. definicja wykonawcy określa w takim samym stopniu przedsiębiorcę budowlanego, dostawcę, a także usługodawcę. Tym samym każdą osobę prawną lub fizyczną, podmiot publiczny albo grupę takich osób bądź też podmiotów, które oferują na runku wykonanie robót albo obiektu budowlanego, produktu bądź usługi. W związku z powyższym katalog podmiotów ubiegających się o udzielenie zamówienia publicznego został określony w sposób bardzo szeroki (Niczyporuk, 2013, s. 98).

Zgodnie z ustawą Pzp w art. 2 pkt 11 definicja legalna wykonawcy została pozbawiona cech przedmiotowych, gdyż poprzez wykonawcę należy obecnie rozumieć osobę fizyczną, osobę prawną albo jednostkę organizacyjną nieposiadającą osobowości prawnej, która ubiega się o udzielenie zamówienia publicznego, złoży ofertę albo podpisze umowę w związku z zamówieniem publicznym. 
Dla pełnego określenia wykonawcy warto zwrócić uwagę na to, że należy wykonawcę oceniać poprzez trzy etapy postępowania o udzielenie zamówienia publicznego. Zdarza się bowiem często, że brak jest odpowiednich podstaw prawnych do rozstrzygnięcia, w sytuacji kiedy konkretny podmiot uzyskuje, a później traci status wykonawcy. Przykładowo, podmiot, który pozyskał specyfikację istotnych warunków zamówienia, a później nie złożył oferty, traci wówczas status wykonawcy. Nadmienić należy jednak, że podmiot uzyskujący status wykonawcy powinien zawsze posiadać podmiotowość prawną, tj. zdolność prawną oraz zdolność do czynności prawnych. Głównie chodzi tu o podmiotowość prawną na zasadach prawa cywilnego, lecz nie wolno zapomnieć o podmiotowości prawnej na gruncie prawa administracyjnego. Wykonawcą bowiem może być również podmiot publiczny. Warto dodatkowo zaznaczyć, że wykonawca nie musi równocześnie posiadać statusu przedsiębiorcy w związku z zapewnieniem pełnej konkurencji, jednak prawie zawsze wykonawca właśnie taki status posiada (Niczyporuk, 2013, s. 99).

Należy również nadmienić, że wykonawcy z mocy samego prawa mogą wspólnie ubiegać się o udzielenie zamówienia publicznego zgodnie z art. 23 ust. 1 Prawo zamówień publicznych. Spośród przyczyn, przez które wykonawcy ubiegają się wspólnie o udzielenie zamówienia publicznego, można najczęściej zauważyć konieczności dostosowania się do rozmiarów zamówienia, jego złożoności oraz zwiększonego ryzyka. Zamawiający w tym celu nie musi dokonywać żadnych czynności, nie jest też koniecznie określenie takiej możliwości w Specyfikacji Istotnych Warunków Zamówienia. Ponadto wykonawcy, którzy wspólnie ubiegają się o udzielenie zamówienia publicznego, mają status identyczny jak samodzielni wykonawcy. Przepisy, które dotyczą wykonawcy, stosuje się bowiem analogicznie do wykonawców wspólnie ubiegających się o zamówienie publiczne według art. 23 ust. 3 Prawo zamówień publicznych. Dlatego też z jednej strony odpowiednie ich stosowanie wiąże się z tym, że nie każdy wykonawca może zostać wykluczony z postępowania o udzielenie zamówienia publicznego. $Z$ drugiej strony natomiast należy w postępowaniu o udzielenie zamówienia publicznego liczyć się z łącznym potencjałem wszystkich, wspólnie ubiegających się o zamówienie wykonawców (Niczyporuk, 2013, s. 99). 
Wykonawca może korzystać także z wiedzy, doświadczenia oraz potencjału technicznego osób zdolnych do wykonania zamówienia bądź zdolności finansowych innych podmiotów. Poprzez to znacznie powiększa się potencjalny zakres wykonawców w odpowiednich sytuacjach, a także w przypadku określonego zamówienia publicznego. Należy również podkreślić, że posiadanie potencjału w podmiocie trzecim podczas postępowania o udzielenie zamówienia publicznego nie zawsze musi się wiązać z koniecznością uczestnictwa tego podmiotu w wykonywaniu tegoż zamówienia publicznego (Niczyporuk, 2013, s. 99-100; Olszewska-Stompel, Stompel, 2017).

Poza powyższą możliwością wykonawca może skorzystać z podmiotu, jakim jest podwykonawca. Instytucja podwykonawcy ma duże znaczenie wobec zagwarantowania sprawności realizacji zamówienia publicznego, przede wszystkim kiedy weźmiemy pod uwagę udział w nim zarówno małych, jak i średnich przedsiębiorców. W stanie prawnym obowiązującym przed nowelizacją ustawy Pzp brakowało przepisów określających w dostateczny sposób wielu zagadnień powiązanych z podwykonawstwem przy udzieleniu oraz realizacji zamówień publicznych. Głównie brakowało uregulowania związanego ze spełnianiem przez wykonawców określonych warunków z reagowaniem przez nich na postawione im wymagania (Niczyporuk, 2013, s. 100).

Choć stosunki występujące pomiędzy wykonawcą zamówienia publicznego i podwykonawcą podlegają co do zasady swobodzie umów, to powodem sprecyzowania przepisów była dalsza potrzeba regulacji statusu podwykonawców celem wzmocnienia prawidłowego wykonywania zamówienia publicznego. Wobec tego w dniu 24 grudnia 2013 r. pojawiły się nowe uregulowania w ustawie Pzp poprzez wejście w życie m.in. art. 143a-143d Prawo zamówień publicznych. Postanowienia z nich wynikające stosuje się wyłącznie względem postępowań wszczętych po dniu wejścia w życie znowelizowanych przepisów. Podstawowym celem powstałego rozwiązania jest wsparcie podwykonawców oraz wzmocnienie ich pozycji wobec wykonawców. Kolejno przepisy mają także pomagać wykonawcom, którym zapewniono, że część wynagrodzenia będzie możliwa do uzyskania przez nich wcześniej niż po wykonaniu całego zamówienia.

Zaznaczenia wymaga, że przepisy art. 143a-143d Pzp (art. 143a-143d ustawy Pzp z dnia 29 stycznia 2004 r.) dotyczą głównie zamówień na roboty 
budowlane, z zaznaczeniem, że część regulacji dotyczy zamówień udzielanych na okres dłuższy niż dwanaście miesięcy. Przepisy są silnie powiązane $z$ definicją umowy o podwykonawstwo, która została wprowadzona do ustawy Pzp także 24 grudnia 2013 r. Zgodnie z art. 2 pkt $9 \mathrm{~b}$ ustawy Pzp poprzez umowę o podwykonawstwo powinno się rozumieć umowę pisemną, odpłatną, której przedmiotem są usługi, dostawy lub roboty budowlane, stanowiące część zamówienia publicznego.

Zgodnie z pojęciem ustawowym, przez umowę o podwykonawstwo należy rozumieć umowę zawartą pomiędzy wybranym przez zamawiającego wykonawcą a innym podmiotem, tj. podwykonawcą, a w przypadku zamówień publicznych na roboty budowlane, także między podwykonawcą a dalszym podwykonawcą lub między dalszymi podwykonawcami.

Natomiast pod określeniem „części zamówienia publicznego” powinno się rozumieć nie tylko określone, poszczególne zadania czy świadczenia, które zostały wskazane w opisie przedmiotu zamówienia, ale także takie usługi czy dostawy, które posiadają charakter pomocniczy dla wyróżnionych zadań, które zostały wskazane przez zamawiającego i których wykonanie podlega wykonaniu zamówienia publicznego. Wobec tego to przedmiot zamówienia, a więc określone usługi, dostawy i roboty budowlane, może podlegać podziałowi na części (Gordon, PZP 2017, Nr 2, s. 3).

Uczestnikami konkursu, zgodnie z art. 118 ust. 1 ustawy Pzp, mogą być osoby fizycznie, osoby prawne, a także jednostki organizacyjne, które nie posiadają osobowości prawnej. Na podstawie ust. 2 wskazanego przepisu, jeśli przepisy szczególne wymagają posiadania uprawnień do opracowania pracy konkursowej, to wówczas uczestnikami konkursu mogą być tylko osoby fizyczne, które posiadają wymagane uprawnienia, albo podmioty, które posługują się osobami fizycznymi posiadającymi określone uprawnienia (Ziółkowska, PZP 2013, Nr 4, s. 59). Katalog uczestników jest zbliżony do przypadku katalogu wykonawców występujących w postępowaniu o udzielenie zamówienia publicznego podczas przebiegu konkursu, zakres podmiotowy uczestników konkursu także ulega zawężeniu. Należy tu wymienić trzy etapy, gdzie status uczestnika konkursu posiadają równe podmioty, tj.: etap po publikacji przez zamawiającego ogłoszenia na temat konkursu w Biuletynie Zamówień Publicznych albo Dzienniku Urzędowym Unii Europejskiej, 
następnie etap po upływie terminu oznaczonego w ogłoszeniu, a także trzeci, ostatni etap - procedury konkursowej.

Po publikacji przez zamawiającego ogłoszenia, o którym to mowa wyżej, uczestnikami konkursu są wszyscy potencjalnie zainteresowani wygraniem pracy konkursowej. Kiedy upłynie termin oznaczony w ogłoszeniu, krąg uczestników ulega stosownemu ograniczeniu co do tych podmiotów, które złożyły wniosek o dopuszczenie do udziału w konkursie. Później ulega zawężeniu krąg uczestników co do takich, którzy złożą pracę konkursową. Na końcowym etapie procedury konkursowej status uczestnika konkursu należy wyłącznie co do tego podmiotu, który otrzyma nagrodę bądź zostanie zaproszony do negocjacji w trybie negocjacji bez ogłoszenia albo zamówienia z wolnej ręki (komentarz do art. 179 ustawy Pzp, Janda, 2013, s. 633).

Jako następną grupę podmiotów, której przysługuje prawo do wniesienia skargi do sądu, ustawodawca wskazał „inne podmioty”. Kategoria ta jest najszersza, a zarazem niedookreślona. Poprzez określenie „inne podmioty” powinno się rozumieć osoby fizyczne, osoby prawne albo jednostki organizacyjne, które nie posiadają osobowości prawne. W związku z powyższym należy wskazać, że „innymi podmiotami” są podmioty, którym nie przysługuje status wykonawcy w postępowaniu o udzielenie zamówienia publicznego albo status uczestnika konkursu. Tak na przykład status „innego podmiotu”, który jest uprawniony do wniesienia skargi, ma podmiot, który ubiegał się o udzielenie zamówienia publicznego, ale nie złożył oferty (Jaworska, 2018).

Zgodnie z ustawą Pzp odwołanie w zakresie ograniczonym mogą wnosić również organizacje, które są wpisane na listę, o której mowa w art. 154 pkt 5 ustawy Pzp, tj. prowadzoną przez Prezesa Urzędu Zamówień Publicznych i ogłaszaną na stronie internetowej Urzędu listę organizacji uprawnionych do wnoszenia środków ochrony prawnej. Artykuł 179 ust. 2 ustawy Pzp stanowi o tym, że takie właśnie organizacje posiadają legitymację do wniesienia skargi. Określić należy, że występowanie ze środkami ochrony prawnej przez powyższe organizacje, w tym ze skargą do sądu włącznie, podlega przedmiotowemu ograniczeniu. Wywodzi to się z tego, że powoływany w niniejszym dziale przepis art. 179 ust. 2 Pzp daje organizacjom uprawnienia do korzystania z przedmiotowego prawa wyłącznie wobec ogłoszenia o zamówieniu, a także specyfikacji istotnych warunków zamówienia (Jaworska, 2018). 


\section{SPOSÓB WNIESIENIA SKARGI}

Przepisy ustawy jako sąd właściwy (właściwość rzeczowa) określa sąd okręgowy właściwy dla siedziby bądź miejsca zamieszkania zamawiającego (Romańska, 2018). Zgodnie z art. 41 kc, jeśli ustawa albo oparty na niej statut nie stanowi inaczej, siedzibą osoby prawnej jest miejscowość, w której ma siedzibę jej organ zarządzający. Natomiast zgodnie z art. $25 \mathrm{kc}$ miejscem zamieszkania osoby fizycznej jest miejscowość, w której osoba ta przebywa z zamiarem stałego pobytu. Siedziba albo miejsce zamieszkania wykonawcy są w zasadzie obojętne. Właściwość sądu okręgowego jest tzw. właściwością wyłączną, co oznacza, że skargę można złożyć tylko do konkretnie wskazanego sądu na podstawie kryteriów określonych w ustawie Pzp (Pokrzywniak, Kwieciński, Baehr, 2006, s. 167-168).

\section{TERMIN DO WNIESIENIA SKARGI}

Skargę wnosi się za pośrednictwem Prezesa Krajowej Izby Odwoławczej z zachowaniem 7 dni od dnia doręczenia orzeczenia do Izby, jednocześnie przesyłając jej odpis przeciwnikowi skargi. Złożenie skargi w placówce pocztowej operatora wyznaczonego $\mathrm{w}$ rozumieniu ustawy $\mathrm{z}$ dnia 23 listopada 2012 r. - Prawo pocztowe jest równoznaczne z jej wniesieniem. Prezes Izby przekazuje skargę wraz z aktami postępowania odwoławczego właściwemu sądowi w terminie 7 dni od dnia jej otrzymania (Pokrzywniak, Kwieciński, Baehr, 2006, s. 644).

\section{WARUNKI FORMALNE ORAZ TREŚĆ SKARGI}

Zgodnie z sentencją wyroku Sądu Okręgowego w Szczecinie (Wyrok sądu okręgowego w Szczecinie z dnia 6 marca 2012 r., sygn. akt VIII Ga 65/12) „doręczenie skargi błędnie stronie, zamiast jej pełnomocnikowi, należy kwalifikować - zważywszy na ratio legis uregulowania przyjętego w art. 198b ust. 2 Pzp - jako brak formalny skargi, podlegający uzupełnieniu w trybie art. $130 \$ 1$ k.p.c. w zw. z art. 198a ust. 2 Pzp". Podczas składania skargi poza argumentacją stanowiska skarżącego, należy mieć zawsze na uwadze pozostałe istotne aspekty tworzenia pisma, a mianowicie warunki formalne, jakie pismo powinno realizować. Zgodnie z art. 198c Pzp, skarga powinna spełniać wymagania przewidziane dla pism procesowych, a także zawierać oznaczenia 
zaskarżonego orzeczenia, określenie zarzutów, właściwe ich uzasadnienie oraz określenie dowodów i wnioski o uchylenie orzeczenia albo o jego zmianę w całości lub w części.

Wobec powyższego pismo powinno zawierać: oznaczenie sądu, do którego jest skierowane, imię i nazwisko oraz nazwę stron, ich przedstawicieli ustawowych, a także pełnomocników. Określenie miejsca zamieszkania albo siedziby stron oraz ich przedstawicieli ustawowych i pełnomocników, a także przedmiot sporu. Oznaczenie rodzaju pisma, osnowę wniosku albo oświadczenia, a także dowody na poparcie przytoczonych okoliczności. Podpis strony albo jej przedstawiciela ustawowego lub pełnomocnika, wymienienie załączników (komentarz do art. 198c ustawy Pzp, Janda, w: Babiarz, Czarniak, Janda, Pełczyński, 2013, s. 671).

Skarga powinna być podpisana przez osoby upoważnione do reprezentacji zgodnie $\mathrm{z}$ odpowiednimi dokumentami rejestrowymi. W razie podmiotów zagranicznych owe dokumenty powinny zostać złożone w oryginałach bądź powinny być to kopie poświadczone przez notariusza za zgodność z oryginałami z tłumaczeniami sporządzonymi przez tłumacza przysięgłego. W razie podpisania skargi przez pełnomocnika należy pamiętać o dołączeniu do pisma również pełnomocnictwa.

W temacie powyższego zagadnienia wypowiedział się Sąd Okręgowy w Warszawie w dniu 15 lipca 2011 r. W przedmiotowym orzeczeniu skład orzekający wskazał, że „dla ustalenia prawidłowego umocowania wystarczające jest pełnomocnictwo udzielone uczestnikom konsorcjum zgodnie z przepisem art. 23 ust. 2 Pzp na potrzeby postępowania odwoławczego. Zgodnie bowiem z przepisami ustawy prawo zamówień publicznych, kwestionowanie zakresu umocowania lidera konsorcjum na etapie postępowania skargowego przed sądem prowadziłoby do przyjęcia, iż w postępowaniu skargowym występują inne podmioty niż w postępowaniu odwoławczym przed Krajową Izbą Odwoławczą" (Wyrok Sądu Okręgowego w Warszawie z dnia 15 lipca 2011 r., sygn. XXIII Ga 416/11).

Wobec wymogów formalnych skargi zdanie swoje wyraził Sąd Najwyższy w uchwale z dnia 23 września 2004 r., twierdząc, że skarga nie musi określać wymogów, które zostały wskazane w art. $386 \$ 1$ kpc, czyli wystarczające jest w zupełności, jeżeli zawiera wniosek o zmianę w całości albo w części orze- 
czenia, bez określenia zakresu żądanej zmiany bądź uchylenia (Wyrok Sądu Najwyższego w uchwale z dnia 23 września 2004 r., sygn. akt III CZP 51/04).

Wskazać należy, że ustawa Pzp nie rozstrzyga w sposób jednoznaczny, czy wymogiem formalnym skargi jest także dołączenie do niej dowodu doręczenia skargi przeciwnikowi procesowemu. Jednak art. 198b ust. 2 Pzp wskazuje, że wnoszącego skargę zobowiązuje się do złożenia jej odpisu przeciwnikowi procesowemu, podczas gdy art. 198c, który określa wymogi formalne skargi, nie wymienia wśród nich dołączenia dowodu przekazania odpisu.

Omawiane powyżej zagadnienie zostało rozstrzygnięte uchwałą Sądu Najwyższego z dnia 8 grudnia 2005 r. w następujący sposób: „niedołączenie do skargi na orzeczenie zespołu arbitrów dowodu przesłania jej przeciwnikowi jest brakiem formalnym". Uchwała ta co prawda została wydana $\mathrm{w}$ stanie prawnym sprzed uchwalenia wielu nowelizacji zmieniających przepisy ustawy, ale mimo wszystko zachowuje ona swą aktualność również w obowiązującym stanie prawnym (Uchwała Sądu Najwyższego z dnia 8 grudnia 2005 r., III CZP 109/05, OSNC 2006, nr 11, poz. 182).

Ustawa Pzp nie przewiduje możliwości złożenia odpowiedzi na skargę, chociaż stronie przeciwnej przysługuje zgodnie z art. 198a ust. 2 Pzp, który dookreślają odpowiednie stosowanie przepisów o apelacji w sprawach nieuregulowanych, w związku z art. 372 kpc możliwość wniesienia odpowiedzi na skargę. Zgodnie ze wskazanym przepisem Kodeksu postępowania cywilnego strona może, choć nie musi, w ciągu dwóch tygodni od dnia doręczenia skargi wnieść na nią odpowiedź i to wprost do sądu. Kodeks postępowania cywilnego przyjmuje termin dwutygodniowy do wniesienia odpowiedzi na skargę. Jest to termin ustawowy, nie podlega więc przedłużeniu przez sąd. Przywrócenie tego terminu nie jest możliwe, gdyż niewniesienie w tym terminie odpowiedzi na apelację nie pociąga za sobą ujemnych skutków procesowych, co jest jednym $\mathrm{z}$ warunków dopuszczalności przywrócenia uchybionego terminu procesowego w art. $168 \$ 2 \mathrm{kpc}$. Strona niewnosząca odpowiedzi albo która wniosła odpowiedź z naruszeniem dwutygodniowego terminu na jej wniesienie, może podnosić także swoje zarzuty i twierdzenia w toku samej rozprawy.

Ponadto zgodnie $\mathrm{z}$ art. 198d Pzp w postępowaniu skargowym nie można rozszerzyć żądania odwołania ani występować z nowymi żądaniami. Należy w tym miejscu przypomnieć, że odwołanie powinno zawierać wskazanie 
czynności albo zaniechanie czynności zamawiającego, której to zarzuca się niezgodność z przepisami ustawy. Powinno również posiadać zarzuty, a także określać żądanie. Trzeba mieć na uwadze, że w odwołaniu nie można zgłaszać żądań, które nie są zawarte w skardze, oraz zgłaszać nowych zarzutów bądź też wskazywać nowych czynności naruszających przepisy ustawy (Janda, w: Babiarz, Czarniak, Janda, Pełczyński, 2013, s. 672).

\section{KOSZTY WNIESIENIA SKARGI}

Skarga podlega opłacie, która została określona w art. 34 ust. 1 ustawy z dnia 28 lipca 2005 r. o kosztach sądowych w sprawach cywilnych (Zieliński, 2015). Zgodnie z wyżej wymienionym artykułem na orzeczenie Krajowej Izby Odwoławczej pobiera się stałą opłatę w wysokości pięciokrotności wpisu, który wnosi się od odwołania w sprawie dotyczącej skargi.

Opisując kwestię wysokości opłaty, jaką trzeba uiścić, kiedy wnosi się skargę na orzeczenie KIO, wskazać należy, że w dniu 14 stycznia 2014 r. Trybunał Konstytucyjny wydał wyrok, w którym stwierdził, że art. 34 ust. 2 ustawy o kosztach sądowych w sprawach cywilnych w zakresie, w jakim określa opłatę stosunkową od skargi na orzeczenie Krajowej Izby Odwoławczej przy Prezesie Urzędu Zamówień Publicznych, jest niezgodny z Konstytucją (Trybunał Konstytucyjny z dnia 14 stycznia 2014 r., sygn. akt: SK 25/11; Stręciwilk, 2014).

Wskazany wyrok zakończył spór, który w doktrynie miał miejsce od czasu znowelizowania przepisów. Wskazana okoliczność nie zmieniła jednak faktu, że opłaty stałe dotyczące czynności zamawiającego dokonane przed otwarciem oferty są bardzo wysokie, nawet dwudziestokrotnie większe od pozostałych opłat stałych, które są przewidziane w ustawie o kosztach sądowych w sprawach cywilnych. Natomiast górny poziom opłaty stosunkowej jest pięćdziesięciokrotnie wyższy od najwyższej opłaty stosunkowej (tak art. 13 ustawy z dnia 28 lipca 2005 r. o kosztach sądowych w sprawach cywilnych).

Ustanowienie tak wysokich opłat jest ciężko uzasadnić i może zostać odebrane jako ograniczenie prawa do sądu. Chcąc ocenić wysokości opłat od skargi na orzeczenie KIO, trudno pomijać fakt, ze Izba nie jest sądem, a ustanowienie takich opłat znacznie utrudnia faktyczne sprawowanie kontroli sądowej nad orzeczeniami Krajowej Izby Odwoławczej. Sytuację 
powyższą dostrzegł Trybunał Konstytucyjny, orzekając w dniu 14 kwietnia 2014 r. (Trybunał Konstytucyjny z dnia 15 kwietnia 2014 r., sygn. akt. SK 12/13), że art. 34 ust. 2 ustawy z dnia 28 lipca 2005 r. o kosztach sądowych $\mathrm{w}$ sprawach cywilnych jest niezgodny $\mathrm{z}$ art. 45 ust. $1 \mathrm{w}$ związku z art. 31 ust. 3, art. 77 ust. 2 i art. 78 Konstytucji. W pozostałym zakresie Trybunał umorzył postępowanie. Trybunał Konstytucyjny stwierdził, że art. 34 ust. 2 uksc narusza prawo dostępu do sądu, a także realizowane przed sądem okręgowym prawo do zaskarżania orzeczeń i decyzji wydanych w pierwszej instancji, wynikające $z$ art. 77 ust. 2 Konstytucji. Dodatkowo art. 34 ust. 2 uksc jest niezgodny $\mathrm{z}$ art. 78 Konstytucji dlatego, że ustanawia nadmiernie utrudnione, tj. nieproporcjonalne, warunki wniesienia środka odwoławczego do sądu, wyłącznie formalnie gwarantując prawo zaskarżenia orzeczenia wydanego w pierwszej instancji.

Według Trybunału o negatywnej ocenie art. 34 ust. 2 uksc (zob. art. 64 $\$ 1 \mathrm{kpc}$ ) przesądza przede wszystkim wadliwe, nieproporcjonalne zakreślenie maksymalnej wysokości opłaty stosunkowej pobieranej od skargi na orzeczenie KIO, gdy dotyczy ona czynności dokonywanych przez zamawiającego po otwarciu ofert. Kwotę 5000000 zł należy uznać za arbitralną oraz wygórowaną. Trybunał uznał, że wszystkie opłaty sądowe w sprawach zamówień publicznych oraz niezależnie od tego, czy dotyczą czynności w postępowaniu o udzielenie zamówienia publicznego podjętych po otwarciu ofert, czy przed tym momentem, będą obliczane według reguł określonych w art. 34 ust. 1 uksc i będą miały charakter stały. Ewentualna zmiana art. 34 uksc leży w dyspozycji ustawodawcy, co dotyczy zarówno możliwości ustalenia nowych wysokości opłat sądowych w sprawach zamówień publicznych, jak również wyboru optymalnego systemu ich obliczania.

\section{TRYB ROZPOZNANIA SKARGI}

\section{(przesłanki odrzucenia skargi - przywrócenie terminu)}

Skargę wniesioną po upływie terminu albo niedopuszczalną z innych przyczyn oraz skargę, której braków strona nie uzupełniła w terminie, sąd odrzuca. Może to uczynić na posiedzeniu niejawnych. Artykuł 198e ust. 1 Pzp reguluje możliwość odrzucenia skargi. Została ona unormowana analogicznie do odrzucenia apelacji w art. 370 kpc. Odrzucenie skargi jest możliwe, gdy: 
1) upływa termin na wniesienie skargi,

2) nie zostaną uzupełnione braki skargi w terminie wyznaczonym przez sąd,

3) skarga będzie niedopuszczalna $z$ innych przyczyn, co oznacza istnienie przeszkody procesowej uniemożliwiającej merytoryczne rozpatrzenie skargi przez sąd okręgowy. W praktyce chodzi o brak zdolności sądowej czy też zdolności do występowania jako strona postępowania (zob. art. $64 § 1 \mathrm{kpc}$ ).

Jak twierdzi M. Jaworska: „Z odrzuceniem skargi jako niedopuszczalnej z innych przyczyn niż wniesienie jej po upływie terminu mamy do czynienia w przypadku braku czynnej legitymacji do jej wniesienia. Skargę, zgodnie z art. 198a ust. 1 i art. 198b ust. 4 Pzp, może wnieść tylko strona postępowania odwoławczego lub jego uczestnik oraz na szczególnych zasadach Prezes UZP. Uczestnikiem postępowania odwoławczego może stać się inny wykonawca ubiegający się o udzielenie zamówienia, jeżeli w terminie przewidzianym w art. 185 ust. 2 Pzp przystąpi do toczącego się postępowania odwoławczego. Skuteczność przystąpienia ocenia KIO, wydając postanowienie o dopuszczeniu do udziału w postępowaniu odwoławczym" (Jaworska, 2018).

Zgodnie z art. 198e ust. 2 Pzp wniesiona skarga do sądu jest czynnością procesową strony. Wobec tego sąd może przywrócić termin do wniesienia skargi przy spełnieniu następujących przesłanek procesowych:

1) wniosku strony, przywrócenie terminu z urzędu nie jest dopuszczalne,

2) złożenia tego wniosku w sądzie w terminie 7 dni od dnia ustania przyczyny uchybienia terminowi,

3) wykazania we wniosku, że uchybienie terminu nastąpiło bez winy strony dokonującej czynności procesowej.

Ocena winy strony należy do sądu. Sąd dokonuje tej oceny przy uwzględnieniu całokształtu okoliczności konkretnego wypadku, w tym jej obowiązek zachowania należytej staranności podczas dokonywania czynności procesowej. Na temat przywrócenia lub odmowy przywrócenia terminu do wniesienia skargi sąd może orzec na posiedzeniu niejawnym. Orzeczenie sądu zapada w formie postanowienia (komentarz do art. 198e ustawy Pzp, Janda w: Babiarz, Czarniak, Janda, Pełczyński, 2013, s. 673; Baehr w: Czajkowski, 2007, s. 426-427). 
Podsumowując, ustawodawca nie ustanowił żadnych szczególnych wymagań związanych z wniesieniem skargi. Wszystkie okoliczności związane z instytucją skargi wskazują, że sąd orzekający na skutek jej wniesienia stanowi drugą instancję rozpoznającą sprawę merytorycznie. Status skargi jako zwyczajnego środka zaskarżenia potwierdził Sąd Najwyższy w uchwale z dnia 6 listopada 2002 r. (uchwała Sądu Najwyższego z dnia 6 listopada 2002 r., III CZP 68/02, OSP 2004, z. 3, poz. 35).

Należy również wskazać kwestię ciężaru dowodu w procesie związanym z prawem zamówień publicznych. Ciężar dowodu, że oferta nie zawiera rażąco niskiej ceny zgodnie z art. 198ea Pzp spoczywa na wykonawcy, który ją złożył, jeżeli jest stroną postępowania bądź interwenientem, albo na zamawiającym, jeżeli wykonawca, który złożył ofertę, nie jest stroną postępowania albo interwenientem (tak art. 198ea ustawy Pzp).

Zgodnie $\mathrm{z}$ art. $198 \mathrm{f}$ ust. 1 Pzp, sąd powinien rozpoznać skargę $\mathrm{w}$ terminie miesiąca od dnia, w którym owa skarga wpłynie. Wcześniej obowiązywał termin trzymiesięczny. Termin jest terminem instrukcyjnym, którego przekroczenie nie pociąga za sobą ujemnych skutków procesowych zarówno dla stron, jak i uczestników postępowania skargowego (komentarz do art. $198 \mathrm{f}$ ustawy Pzp, Janda, w: Babiarz, Czarniak, Janda, Pełczyński, 2013, s. 674).

Sąd oddala skargę w sytuacji, kiedy jest ona bezzasadna. W sytuacji uwzględnienia skargi sąd zmienia orzeczenie i orzeka wyrokiem co do istoty sprawy, a w pozostałych kwestiach sąd wydaje postanowienie. Sąd nie ma uprawnień do uchylenia orzeczenia izby oraz przekazania sprawy do ponownego rozpoznania. Podczas podejmowania rozstrzygnięcia sąd, analogicznie do Izby, powinien brać pod uwagę to, czy została zawarta umowa w sprawie udzielenia zamówienia publicznego. Jeśli umowa nie została zawarta, sąd, poprzez uwzględnienie skargi, zmienia orzeczenie Izby oraz nakazuje dokonanie, powtórzenie albo unieważnienie czynności zamawiającego. W sytuacji natomiast, kiedy umowa została zawarta, sąd podczas uwzględnienia skargi unieważnia umowę albo stosuje kary alternatywne poprzez nałożenie kary finansowej bądź skrócenie okresu obowiązywania umowy. Podczas orzekania w tym zakresie sąd kieruje się identycznymi przesłankami do tych, które będzie stosowała Izba. Jeśli będą zachodziły podstawy do umorzenia postępowania albo odrzucenia odwołania, sąd uchyla wyrok albo zmienia postano- 
wienie bądź też odrzuca odwołanie lub umarza postępowania. Sąd nie orzeka co do zarzutów, które nie były przedmiotem odwołania.

Wskazać należy, że strony ponoszą koszty postępowania skargowego odpowiednio do jego wyniku, natomiast sąd, poprzez określenie wysokości kosztów, uwzględnia również koszty poniesione przez strony w wyniku rozwiązania odwołania (tak komentarz do art. 198f ustawy Pzp, Janda, w: Babiarz, Czarniak, Janda, Pełczyński, 2013, s. 674).

W postępowaniu toczącym się wskutek wniesienia skargi, sąd może:

1) oddalić wyrokiem skargę, jeśli skarga okaże się bezzasadna,

2) uwzględnić wyrokiem skargę, jeżeli ta okaże się zasadna, wówczas, w zależności od zaistniałego stanu faktycznego, sąd może zmienić zaskarżony wyrok oraz orzec wyrokiem co do istoty sprawy, np. zmienić wyrok, uwzględniając odwołanie i swoim wyrokiem oddalić odwołanie bądź też zmienić wyrok zaskarżony skargą w zakresie niedotyczącym istoty sprawy, czyli w praktyce w zakresie kosztów postępowania odwoławczego oraz orzec w tej kwestii postanowieniem,

3) uchylić postanowieniem wyrok Krajowej Izby Odwoławczej oraz odrzucić odwołanie, jeżeli zachodzą podstawy do odrzucenia odwołania określone w art. 189 ust. 4 Pzp. Co prawda art. $198 \mathrm{f}$ ust. 3 Pzp nie rozstrzyga równocześnie, czy w przypadkach, kiedy odwołanie zostaje odrzucone, to sąd powinien wydać wyrok czy też postanowienie, jednak już art. $198 \mathrm{f}$ ust. 2 Pzp wyraźnie stanowi, że sąd wydaje wyrok wyłącznie wówczas, kiedy rozstrzyga sprawę w sposób merytoryczny, czyli co do istotny sprawy. W innych sprawach sąd wydaje postanowienie, a to należy rozumieć tak, że wówczas, kiedy odrzucenie odwołania ma miejsce na skutek wydania orzeczenia przez sąd okręgowy w postępowaniu skargowym, sąd powinien to uczynić postanowieniem,

4) uchylić poprzez postanowienie wyroku Krajowej Izby Odwoławczej oraz umorzyć postępowanie odwoławcze, jeśli odwołujący cofnął w sposób skuteczny odwołanie, a mimo to skład, który orzekał, orzekł co do istoty sprawy (Stachowiak, Jerzykowski, Dzierżanowski, 2012).

Zaznaczenia również wymaga to, że art. 198f ust. 5 Pzp określa zasadę orzekania o kosztach postępowania w sprawach ze skargi na orzeczenie, Izby 
i wprowadza jako wyłączną regułę odpowiedzialności za wynik postępowania. W przedmiotowym zakresie wyłącza zatem odpowiednie stosowanie postanowień o kosztach procesu, które są przewidziane w Kodeksie postępowania cywilnego (komentarz do art. 198f ustawy Pzp, Janda, w: Babiarz, Czarniak, Janda, Pełczyński, 2013, s. 674).

Sąd Najwyższy w postanowieniu z dnia 8 sierpnia 2012 r. (postanowienie Sądu Najwyższego z dnia 8 sierpnia 2012 r., I CZ 62/2012, Legalis nr 544085) wskazał, że powiązanie orzeczenia o kosztach wraz z wynikiem postępowania stanowi wyraz akcesoryjności obowiązku pokrycia kosztów przez tę stronę, która uległa, na rzecz tej strony, której to żądania zostały wzięte pod uwagę, tzn. zostały uwzględnione. Należy przez to rozumieć wynik rzeczywisty, tj. stan rzeczy, jaki ma nastąpić wskutek realizacji orzeczenia albo jaki już nastąpił w związku z uwzględnieniem żądań przez przeciwnika. Wzięcie pod uwagę żądania poprzez przeciwnika procesowego połączone $z$ rezygnacją złożoną przez strony z orzeczenia w sprawie przez sąd, które nie budzi wątpliwości co do bezzasadności wydawania merytorycznego orzeczenia, powoduje stan równoważny przegraniu sprawy przez stronę, która jest pozwana, i nie daje możliwości, aby sąd przyjmował za podstawę orzeczenia o kosztach innego, przypuszczalnego oraz niemogącego się już zrealizować rozwiązania sprawy.

\section{SKARGA KASACYJNA PREZESA URZĘDU ZAMÓWIEŃ PUBLICZNYCH}

Zgodnie $\mathrm{z}$ brzmieniem art. 198g od wyroku sądu albo postanowienia kończącego postępowanie w sprawie nie przysługuje skarga kasacyjna. Wyłącznie Prezes Urzędu może wnieść skargę kasacyjną. Wobec przedmiotowego artykułu stosuje się odpowiednio przepisy kpc o prokuraturze generalnej. Prokurator generalny może oprzeć skargę kasacyjną na następujących podstawach: na naruszeniu prawa materialnego poprzez błędną jego wykładnię lub niewłaściwe zastosowanie, na naruszeniu przepisów postępowania, jeśli uchybienie to mogło mieć istotny wpływ na wynik sprawy, jeżeli przez wydanie orzeczenia doszło do naruszenia podstawowych zasad porządku prawnego, art. $398^{3} \$ 1$ i 2 kpc (tak komentarz do art. 198g ustawy Pzp, Janda, w: Babiarz, Czarniak, Janda, Pełczyński, 2013, s. 675). 
Prezes Urzędu uprawniony jest do wniesienia skargi kasacyjnej w terminie 6 miesięcy od dnia uprawomocnienia się orzeczenia, a jeśli strona zażądała doręczenia orzeczenia $\mathrm{z}$ uzasadnieniem, od chwili doręczenia orzeczenia stronie (art. $398^{5} \$ 2 \mathrm{kpc}$ oraz także w przypadku, kiedy nie uczestniczył w postępowaniu przed sądem, którego orzeczenia skarga kasacyjna dotyczy).

Skarga kasacyjna wniesiona przez Prokuratora Generalnego może opierać się na identycznych podstawach jak skarga wnoszona przez samą stronę. Prokurator Generalny powinien wykazać w skardze kasacyjnej, w jaki sposób zaskarżone orzeczenie narusza podstawowe zasady porządku prawnego albo konstytucyjne wolności czy też prawa człowieka oraz obywatela. Zaistnienie tych przesłanek nie jest pozostawione ocenie podmiotów wnoszących skargę i podlega kontroli Sądu Najwyższego (Sieradzka, 2018).

Przyznanie Krajowej Izbie Odwoławczej nowych kompetencji w postaci unieważnienia umów w sprawie zamówienia publicznego powinno stanowić przyczynę do sprawdzenia dotychczasowych postanowień ustawy, które uniemożliwią stronom postępowania skargowego wnoszenie skargi kasacyjnej do Sądu Najwyższego. Artykuł 198g ust. 1 Pzp został zbudowany w taki sposób, że uniemożliwia stronom postępowania skargowego wniesienie skargi kasacyjnej nawet w sprawach o najwyższej wartości przedmiotu zaskarżenia, a nazywanego na podstawie art. 34 uksc - wartością przedmiotu zamówienia, nie koresponduje w najmniejszym stopniu z podstawowymi założeniami procesu cywilnego, który prowadzi do powstania paradoksów (May, 2017, s. 30).

Podczas gdy sąd powszechny orzeka o nieważności umowy w sprawie zamówienia publicznego (rozpoznając powództwo z art. $189 \mathrm{kpc}$ ), wówczas stronom tego procesu będzie przysługiwać prawo do wniesienia skargi kasacyjnej, jeśli wartość zaskarżenia jest większa niż 50000 zł. Tym samym jeśli w sprawie unieważnienia umowy zamówienia publicznego rozstrzyga Krajowa Izba Odwoławcza, to stronie nie przysługuje skarga kasacyjna od wyroku albo postanowienia kończącego postępowania skargowe. Ciężko wobec takiej treści przepisów zrozumieć, czemu kontrola sądowa orzeczeń organu, który nie jest sądem, jest mniejsza od kontroli orzeczeń sądowych. 


\section{Podsumowanie}

Reasumując, analiza dostępnej literatury, komentarzy oraz orzecznictwa potwierdziła zawiłość oraz złożoność Prawa zamówień publicznych, jak również to, jak istotne dla uczestników postępowania zamówień publicznych są środki ochrony prawnej, w tym w szczególności skarga do sądu jako środek umożliwiający zmianę zaskarżonego orzeczenia wydanego przez Krajową Izbę Odwoławczą. Jednocześnie zauważalny jest brak równej dostępności do złożenia przedmiotowego środka zaskarżenia przez uczestników zamówień publicznych, co związane jest między innymi z wysokimi kosztami złożenia skargi do sądu. Pojawia się wątpliwość, czy wysokość opłat za skargę oraz zawiłość samej procedury nie stanowią swego rodzaju ograniczenia prawa do sądu. Procedurę rozpatrywania złożonych skarg należy ocenić jako rygorystyczną. Skarga składana na podstawie przepisów ustawy Prawa zamówień publicznych wiąże się z wieloma utrudnieniami. Przede wszystkim uczestnicy postępowania stają przed dylematem związanym z podjęciem decyzji, czy kierować do sądu skargę, która może narazić ich na długi oraz kosztowny proces.

\section{Wykaz aktów prawnych}

Konstytucja Rzeczypospolitej Polskiej z dnia 2 kwietnia 1997 r. (Dz.U. z 1997 r., $\mathrm{Nr} 78$, poz. 483 ze zm.).

Ustawa z dnia 14 czerwca 1960 r. Kodeks postępowania administracyjnego (tekst jednolity: Dz.U. z 1980 r., Nr 9, poz. 26 ze zm.).

Ustawa $\mathrm{z}$ dnia 17 listopada $1964 \mathrm{r}$. Kodeks postępowania cywilnego (tekst jednolity: Dz.U. z 2014 r., poz. 101 ze zm.).

Ustawa Prawo zamówień publicznych z dnia 29 stycznia 2004 r. (tekst jednolity: Dz.U. z 2006 r., Nr 164, poz. 1163 ze zm.).

Ustawa o kosztach sądowych w sprawach cywilnych z dnia 28 lipca 2005 r. (tekst jednolity: Dz.U. z 2010 r., Nr 90, poz. 594 ze zm.).

Dyrektywa Parlamentu Europejskiego i Rady 2014/24/UE z dnia 26.2.2014 r. w sprawie zamówień publicznych, uchylająca dyrektywę 2004/18/WE (Dz.U. L 94 z 28.3.2014, s. 65). 


\section{Orzecznictwo}

\section{Trybunal Konstytucyjny:}

Trybunał Konstytucyjny z dnia 14 stycznia 2014 roku (sygn. akt: SK 25/11, Legalis nr 746858).

Trybunał Konstytucyjny z dnia 15 kwietnia 2014 roku (sygn. akt. SK 12/13, Legalis nr 810331).

\section{Sąd Najwyższy:}

Uchwała Sądu Najwyższego z dnia 6 listopada 2002 r. (III CZP 68/02, OSP 2004, z. 3, poz. 35).

Uchwała Sądu Najwyższego z dnia 8 grudnia 2005 r. (III CZP 109/05, OSNC 2006, nr 11, poz., 182).

Uchwała Sądu Najwyższego z dnia 23 września 2004 r. (sygn. akt III CZP 51/04).

Postanowienie Sądu Najwyższego z dnia 8 sierpnia 2012 r. (I CZ 62/2012, Legalis nr: 544085).

\section{Sąd Okręgowy:}

Wyrok Sądu Okręgowego w Warszawie z dnia 15 lipca 2011 r. (sygn. XXIII Ga 416/11).

Wyrok Sądu Okręgowego w Szczecinie z dnia 6 marca 2012 r. (sygn. akt VIII Ga 65/12).

Postanowienie Sądu Okręgowego w Warszawie z dnia 3 kwietnia 2003 r. (sygn. akt: V Ca 1514/03).

Postanowienie Sądu Okręgowego w Krakowie z dnia 7 kwietnia 2005 r. (sygn. akt: II Ca 474/05).

\section{Literatura}

Babiarz, S., Czarnik, Z., Janda, P., Pełczyński, P. (2013). Prawo zamówień publicznych, Wielkie Komentarze, Warszawa: LexisNexis Polska. ISBN 9788378069959.

Baehr, J. (2006). Prawo zamówień publicznych. Komentarz. W: Czajkowski T. (red.) Prawo zamówień publicznych. Komentarz, Baehr, J., Czajkowski, T., Dzierżanowski, W., Kwieciński, T., Łysakowski, W., wyd. III, Warszawa: Urząd Zamówień Publicznych. ISBN 8388686658. 
Dolecki, H. (red.) Wiśniewski, T. (2011), Kodeks postępowania cywilnego. Komentarz, t. I, Warszawa: Wolters Kluwer. ISBN 9788326441189.

Góra-Błaszczykowska, A. (red.), (2016), Kodeks postępowania cywilnego. Tom I. Komentarz. Art. 1-729, Warszawa: Wydawnictwo C.H. Beck. ISBN 9788325573751.

Jakubecki, A. (red.), Bodio, J., Demendecki, T., Marcewicz, O., Telenga, P., Wójcik, M.P. (2005). Kodeks postępowania cywilnego. Praktyczny komentarz, wyd. I, Kraków: Zakamycze. ISBN 837444150X.

Janda, P. (2013). Prawo zamówień publicznych. Wielkie Komentarze. W: Babiarz, S., Czarniak, Z., Janda, P., Pełczyński, P., Warszawa: LexisNexis Polska. ISBN 9788378069959.

Jaworska, M. (2018). Środki ochrony prawnej. W: Prawo zamówień publicznych. Komentarz, Jaworska, M (red.), Grześkowiak-Stojak, D., Jarnicka, J., Jaworska, M., Marusiak, A., Warszawa: Wydawnictwo C.H. Beck. ISBN 9788381285681.

Marszałkowska-Krześ, E. (red.), (2018), Kodeks postępowania cywilnego. Komentarz. W: Gill, I., Budniak-Rogala, A., Guzińska, A., Niedużak, A., Zawistowski, D., Marszałkowska-Krześ, E., Mazur, M., Rudkowska-Ząbczyk, E., Biedroń, I., Gibiec, J., Krześ, M., Krej, M., Krej, N., Gil, P., Warszawa, wyd. 23, Legalis.

Niczyporuk, J. (2013). System zamówień publicznych w Polsce. W: Sadowy, J. (red.), Jędrzejewski, R., Niczyporuk, J., Nowicki, H., Nowicki, P., Sołtysińska, A., Szostak, R., Wierzbowski, M., Warszawa: Urząd Zamówień Publicznych. ISBN 9788388686269.

Pokrzywniak, J., Baehr, J., Kwieciński, T. (2006). W: Wprowadzenie do systemu zamówień publicznych, Warszawa - Katowice: Urząd Zamówień Publicznych. ISBN 9788389410511.

Pokrzywniak, J., Kwieciński, T., Baehr ,J. (2006). Środki ochrony prawnej w procedurach zamówień publicznych, Warszawa - Katowice: Urząd Zamówień Publicznych.

Sieradzka, M. (red), 2018. W: Prawo zamówień publicznych. Komentarz, Sieradzka, M. (red), Kotowicz, B., Sieradzka, M., Szustakiewicz, P., Krótkie Komentarze Becka. Warszawa: Wydawnictwo C.H. Beck. ISBN 9788381285704.

Stachowiak, M., Jerzykowski, J., Dzierżanowski, W. (2012). Prawo zamówień publicznych, Warszawa: Wolters Kluwer Polska. ISBN 9788326438516.

Zieliński A, (2015). Koszty sądowe w sprawach cywilnych. Komentarz, wyd. 9, Warszawa, Legalis. 


\section{Inne źródła}

Gordon, Z. (2017), Podział zamówienia publicznego na części, Prawo Zamówień Publicznych 2017, Nr 2, s. 3. ISSN 1733-0777.

May, J. (2017). Funkcjonowanie kontroli sądowej nad orzecznictwem Krajowej Izby Odwoławczej, Prawo Zamówień Publicznych 2017, Nr 2, s. 30. ISSN 1733-0777.

Olszewska-Stompel, J., Stompel, M. (2017). Skuteczność udostępniania potencjału technicznego oraz ekonomiczno-finansowego. Interpretacje/Wyjaśnienia, Zarządca-Doradca 2017, Nr 8. ISSN 1231-8841.

Romańska, M. (2018). Skarga do sadu na orzeczenie Krajowej Izby Odwoławczej $w$ systemie środków zaskarżenia. Kontrola instytucyjna orzeczeń Krajowej Izby Odwoławczej. Część druga, Zarządca-DORADCA, Nr 2, s. 34. ISSN 1231-8841.

Stręciwilk, M. (2014). Zaskarżanie wyniku przetargu w świetle poglądów orzecznictwa, Prawo Zamówień Publicznych 2014, Nr 2, s. 45. ISSN 1733-0777.

Ziółkowska, M. (2013). Charakter prawny konkursu w zamówieniach publicznych, Prawo Zamówień Publicznych 2013, Nr 4, s. 59. ISSN 1733-0777. 
